\title{
ATP2A2 Gene
}

National Cancer Institute

\section{Source}

National Cancer Institute. ATP2A2 Gene. NCI Thesaurus. Code C106416.

This gene plays a role in cardiac muscle contraction. 